\title{
Factors that affect Women Participation in Leadership and Decision Making Position
}

\section{Endale Alemu Hora}

Department of Sociology and Social Work, Jimma University Collage of Social Sciences, Ethiopia

Volume 1, Number 2/2014

DOI:

Licensed:

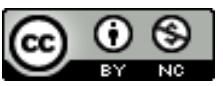

Source of Support: Nil

Conflict of Interest: None declared

Email for correspondence: endo_aau@yahoo.com

\section{ABSTRACT}

This study aimed to identify status of women in Bedele town administration, as well point out factors hindering women from the participating in public and forward some possible recommendations for solving the problems identified through study. Primarily, the study is of descriptive in nature and survey method was used in data gathering. Data used in this paper is mainly primary but to some extent secondary data as well, quantitative and qualitative types was incorporated. In doing this research paper, of total employees existing in Bedele Town administration, 108 (30\% of total population) sample respondents were selected using systematic random sampling method, and were placed questionnaires containing open ended and closed ended nature questions personally, $103(95.37 \%)$ of them had filled and returned the questionnaire. In addition, a mayor of the town and Women Affair office head were addressed through interview using interview guide. In way of analyzing data, techniques such as tabulation, percentages, chart and the like has been employed. Study revealed that, in public institutions existed in Bedele Town, the majority of women were having an educational status of diploma and lower, holding lower non decision making and leadership positions, and observed major barriers hindering women from public leadership and decision-making positions include: Socio-cultural attitudes and lack of acquisition of the necessary experience for taking part in public decision-making, Over burden of domestic responsibilities continuation of the negative attitudes regarding women's ability to lead and govern, Lack of role models of women leaders for young women and girls, and the like can be stated. Finally, the researcher has forwarded some possible ways in which women could appear in public decision making and leadership.

Key words: Affirmative action, Leadership, Gender class ceiling, Empowerment, Decision Making Process, Ethiopia

\section{INTRODUCTION}

In most patriarchic societies, females are regarded as the inferior of the species. Because of this, women are denied access to both honored and utilitarian role open only to males. Such roles as administration and disposal of property, leader ship roles in societal affairs 
including religion and governance are exclusively belong to males. Even the right of choice in respect to entry to conjugal union is denied to women. While it is known that such discriminatory practices exist in these countries, their prevalence and cultural value systems and norms that perpetuate them are not adequately understood.

Sustainable and all around developments of a society cannot be brought about without the full and unreserved participation of both woman and man in the development process, and such a balanced development should also call for the elimination of all forms of discrimination, and the protection against all forms of violence against women. According to WB (1998), although women constitutes two third of the world's working hours, produce half of the world's food and above all, bear and rear children, women continue to suffer from all forms of discrimination and from the absence of adequate protection against violence (WB,1998:137).

According to Meaza (2009), Ethiopia is party to all major human right treaties including the most important women's conventions, i.e., CEDAW which calls for equal participation of women in public decision making, Beijing Declaration and Platform of Action (BDPA), which requires governments to attain a 30\% benchmark for women's representation in all public decision making positions (Meaza,2009:42). Moreover, various literatures argue that as compared to prior decades, the participations women in decision making throughout the world are somehow increasing. But, in spite of the incremental progress towards women's participation in public spheres, it is generally recognized that women have largely remained outside of formal leadership roles due to various factors.

Accordingly, as it was stated by Meaza, the main factors which have contributed for such disparities include: structural barriers, unequal socio-economical opportunities, and inadequate access to mentors and support networks (Meaza, 2009:6). Furthermore, the same source have depicted out that rigid work place structure and gender stereotypes that relate socially defined characteristics with certain groups in most cases also dissociate women from leadership roles (ibid.). The importance of this research bases on the bases the idea that attitudes toward women in leadership affect women's participation in leadership, and in turn, women in positions of leadership engage in policies that positively affects women (Caiazza, 2004). This reciprocal effect furthers the process of gender equality in the work force, and promotes an environment where women are supported to move into autonomous and independent activities. This process gradually leads to further acceptance of women in business or political leadership.

Traditional and persistent barriers have been shown to hinder the active pursuit of women to obtain positions of leadership (i.e. Bartol et al., 2003; Hoyt, 2005; Powell et al., 2002); this point is not contested here and is respected as a foundation of the field. It is proposed here that with the globalization of business practices, opportunities, technologies, and cultures, women face new and different challenges that vary depending on the context of the environment in which they operate.

Hence, the main aim of this study is to dig out major factors that have been affecting women to participate in leadership and decision making roles so as to contribute more their part in nation's affaires. Accordingly, this research has been conducted to investigate and answer the following main research questions:

- What are the status of women in leadership and decision making in public institutions of the Town Administration under study?

- What are the major barriers that hinder women to have access in leadership and decision making roles? 
- What policies and programs should interfere to increase the involvement of women in leadership of public institutions?

\section{OBJectives OF THE STUdY}

The overall objective of the study was to investigate the status of women's participation in leadership and decision making positions of public institutions and the factors that affect their participation in Bedele Town Administration.

The specific objectives of the study include:

- To examine the current status of women in leadership of public institution of Bedele town Administration.

- To identify the major barriers those are affecting the access of women in to management positions.

\section{Research Design and Methodology}

\section{TYPE OF RESEARCH}

The type of study used for the purpose of study is descriptive study. It has been used because it is a fact finding study with adequate and accurate interpretation of the finding. It describes what the reality is. It describes what actually exists within a situation, such as current practices, situations, etc of different aspects of the research. Since the present study is concerned with assessing about factors that are affecting women participation in leadership and decision making in public institution of Bedele Town Administration, the researcher has assumed that the descriptive type of research was the most appropriate method to be used.

\section{DATA SOURCES}

To attain the aim of this study, both primary and secondary data has been used.

Primary Data Sources: The Primary data are gathered from sample respondents (whom are primary Sources) which were chosen through sampling from the total study population.

Secondary Data Sources: The main sources used for secondary data are Annual women affair office report, different books in the area of sociology, management \& leadership, participation of women in public administration etc, internet (mostly, IPU, UNDP, WB, UN etc web sites) and other documented sources from Town administration communication Affair office, and used as references.

\section{POPULATION AND SAMPLE SIZE}

Study Population: Study population is an aggregation of elements from which the sample is actually selected. Accordingly, the study population of this research paper was all permanent employees which currently exist in a total of 23 public institutions of Bedele Town Administration, and are 357 in number.

Sample size: To carry out this study/to assess factors that affect women's participation in leadership and Decision making in public institution, out of the total 357(M 227 and F 130) employees which are currently working in public institution of the town, about $30 \%(107)$ from all public institutions, and two individuals: one from women Affair Office and the other from Mayor office of the Town (which have been selected purposively) has been selected as a sample respondent. 
This is decided because as the sample size increases the reliability of the study increases and can show the real situation of factors that hinder women from leadership and public decision making positions and actual status of women in the town.

\section{SAMPLING TECHNIQUES}

To select sample respondents from total study population, both probability and nonprobability sampling methods were employed. The probability sampling method was selected because it avoids biasness and helps to generalize data gained from sample respondents avoiding an error which could arise from sampling. Therefore, in case this simple random sampling (specifically lottery method to identify the first respondent out of the first 4 th s) and systematic sampling method has been used.

Moreover, purposive sampling has also been used as a technique so as to include Women Affair Head and Mayor of the Town as a respondent. It is decided to use this method in order to include those management bodies and gain relevant data concerning all available data about the status factors affecting the participation of women in leadership and decision making in public institution of the town under study.

\section{METHOd OF DATA COLLECTION}

The method of data collection method which has been employed to this study was survey method, and the data collection tool that has been used to gather data from sample respondents was questionnaire and interview. The questionnaire had contained both closed and open ended formats. The questionnaire was selected because; it helps to gather data with minimum cost faster than any other tool. Moreover, all the respondents will be literate. So, they can read and answer the questionnaire more freely to express their idea on the issue. In addition to this, interview is selected because this helps to get some facts related to the issue under the study from top official of the town administration who are there to implement the government policy.

\section{Method of Data AnALYsis}

As it is stated under the sub topic of 'type of research', this research is of descriptive type. Accordingly, for realization and successful accomplishment of the study, data collected from different primary and secondary sources were recorded, edited, organized, analyzed, interpreted and presented in relation to research questions. This is done both quantitatively and qualitatively by using descriptive statistical tools such as tables, figures, percentages, graphs and charts for data collected through questionnaires, whereas description of finding is used for data collected through interview and observation.

\section{LITERATURE REVIEW}

\section{General Situation OF Women in Ethiopia}

Women comprise about $49.9 \%$ of the estimated Ethiopian population of 77.1 million (CSA, 2007). Among the total heads of households, $25.5 \%$ are females with $23 \%$ of them in rural and $39 \%$ in urban areas (ibid.). Like their counterparts in developing countries, women in Ethiopia face a set of multiple, cross cutting and interrelated problems. These problems limit Ethiopian women's access to productive resources, basic health services, and educational and employment opportunities. Hence most of them do not participate in decision making processes (Sosena \& Tsehai, 2008) 
In general, Women in Ethiopia occupy low status in the society. In spite of their contributions to the well being of their family and community affairs in genersal, women experience lower socio-economic status as a whole and hence is marginalized from making decisions at all levels. Women are facing multiple forms of deprivation. Gender based discrimination, lack of protection of basic human rights, violence, lack of access to productive resources, education and training, basic health services, and employment are widespread (National Committee for Traditional Practices Eradication (NCTPE), 2003).

Ethiopian women suffer from work stereotype and gender distribution of labor, more are occupy in economically invisible work. Women experience lower socioeconomic status in general and hence is marginalized from making decisions at all levels. Nonetheless, women are poor in terms of access to resources, services and employment. Women are underrepresented in the formal sector of employment. The survey conducted by the Central Statistical Authority (CSA, 2004) showed that women account for less than half $(43 \%)$ of the total employees in the country. Considering the percentage of female employees from the total number of employees by employment type, the highest was in domestic activities (78\%) and followed by unpaid activities (59.3\%). In other types of formal employment (e.g. government, NGOs, private organizations), the percentage of female workers is less than 35.

On the other hand, the survey showed overrepresentation of female workers in the informal sector. About 58\% of working women work in the informal sector whereas the percentage of working men in the informal sector was $37.7 \%$ (ibid). The breakdown of the federal government employees by occupational groups also indicated gender disparity. From federal government employees found in the clerical and fiscal type of jobs $71.3 \%$ were female, while the percentage of females was slightly more than half $(51 \%)$ in custodial and manual type of jobs. Women make up $25 \%$ and $18 \%$ of the administrative and professional and scientific job categories, respectively, indicating that upper and middle level positions are overwhelmingly dominated by men (Federal Civil Service Commission, 2005). This concentration of women in the informal sector and low level positions has implication on their earnings. In this regard, the survey showed four out of ten women civil servants earn Birr 300 a month compared to two out of ten for men (Federal Civil Service Commission, 2005).

Generally, regardless of women's immense contribution, they often lack productive assets particularly land, and are underserved with agricultural extension, credit, labor, oxen and farm implements. Women's representation in the permanent employment of both regional and federal civil services is also lower than men; in comparison to the large number of unemployed women. The increase in the number of women employees over the years is insignificant. Women's employment in the formal sector both in industries and the Civil Service is lower than men (NCTPE, 2003).

\section{LEADERSHIP AND POWER}

Power refers to ability to control in such a situation (circumstances) when other human beings must obey and do what the duty requires. According to $\mathrm{M}$. Weber, power is the ability to impose one's will in social relations despite any resistance and without reference to basis of this opportunity. Political power is a definite aspect in relations between large social groups (subjection, cooperation and social partnership).

The exercise of political power is related to needs, interests which are complied with and implemented in social groups. The term "politics" refers to the exercise of power. It is used to describe the key interests of social groups, citizen participation in state duties and also 
to characterize the main directions in the operation (economic, national, social, cultural etc.) of the State and parties (Murnieks 2003).

In any society individuals play some roles, and one of such is the role of a leader. Usually a leader is the one who bears the biggest responsibility; it is the most powerful role in an organization (Byers 1997). The most common opinions about leaders are that they deal with everything and give directions: leaders have power, all the gains and pursuing an objective is only an object of interest of a leader (Gardener 1990). Other employees are called followers, even if they are leaders of a lower group or fulfill some duties of a leader. The concept of leadership involves relationships deeply rooted in social settings (Bryman, 1996) requiring leadership theory and research to integrate leader attributes and behaviors within contextual aspects of leader emergence and effectiveness (G. Yukl, 1998; G. Yukl \& Howell, 1999).

According to Khabele and Victor (2008) Leadership can be defined organisationally and narrowly as 'the ability of an individual to influence, motivate, and enable others to contribute toward the effectiveness and success of the organisations of which they are members'. Organisationally, leadership has a direct impact on the effectiveness of costs, revenue generation, service, satisfaction, earnings, market value, share price, social capital, motivation, engagement and sustainability.

Leadership is even used as a universal means for any social problem. Leadership exists only in relationships and perception of employees involved (Yukl 1994). In order to define leadership it is of major importance to understand relationship (Kouzes and Posner 1995). Leadership is a process when one individual affects the rest of the group in order to achieve defined aims of an organization or a group (Byers, 1997).

An idealistic opinion of theoreticians on the phenomenon of leaders would be as follows: leaders must be able to guide and paint the vision with confidence, and everyone must be ready to believe that this leader is able to achieve the aim (Kouzes and Posner 1995). Most often this role is executed by men. Leadership should not be mixed up with status. It is not quite like that status stands apart from a leader, however very often position brings along only symbolic values and traditions which do not increase the role of a leader (Gardner 1990). For example, a nation awaits a manager to govern the State, yet his/her high position does not imply that his/her leadership is going to be successful. Status is a value, importance or a prestige attached to a position or a role in an organization.

Leader is not the same as a manager, although these two notions get confused. Different role of a manager and a leader may be explained with an example of authority. Weber (Weber, 1947) links authority with legitimacy. People will accept leadership voluntarily as long as they believe that this leadership is legitimate. Authority and leadership have developed from legitimacy and optional recognition, namely, if leadership loses its legitimacy, the ability to manage is lost as well. Obedience to leadership is more optional than forced. Kotter (1988) defines governance as planning, organizing and controlling, while leadership includes creation of a vision and formation of relationships (Bolman and Terrence 1997). Managers promote stability while leaders head for innovation, press for change and find motivation in their employees to complete their tasks. For example, Bennis Warren (1985) finds that managers do things right, but leaders do the right thing (Gardner 1990).

\section{WOMEN AND LEADERSHIP IN ETHIOPIA}

A woman is an adult female human being, as contrasted to men, an adult male, and a girl, a female child. The term woman (irregular plural: women) is used to indicate biological sex distinctions, cultural gender role distinctions, or both (Wikipedia, 2005:1). Ethiopia is a patriarchal society that keeps women in a subordinate position (Haregewoin and Emebet, 
2003). There is a belief that women are docile, submissive, patient, and tolerant of monotonous work and violence, for which culture is used as a justification (Hirut, 2004).

Like many African Countries, the majority of Ethiopian women hold low status in the society. Different studies indicated the low status of women in developing countries in general and in Ethiopia in particular (Almaz, 1991; Hirut, 2004; Mukuria et al., 2005).They have been denied equal access to education, training, and gainful employment opportunities, and their involvement in policy formulation and decision making processes ahs been minimal. Obviously, women play a vital role in the community by taking care of all societal activities. However, they do not enjoy the fruits of their labor and suffer from political, economical, societal, and cultural marginalization. According to Meaza (2009), although there are many women who have played important political and leadership roles in the history of Ethiopia, only few are visible in the existent literatures (Meaza, 2009). The same source has indicated that women have played important political roles mostly by wielding proxy power through birth or marriage.

In support to this idea, as Teshome (1979) stated, in Ethiopian history, women did great contributions in both out and in door activities especially in battles and other activities. They have been actively participating in rural area in agriculture, commercial, undertaking reproduction and social responsibilities. However, their misfortunes of living in the shadow of men have hidden from view such highly notable performances. They have been forced to lose confidence in them selves and so have been unable to act on their own action directly concerning themselves.

Literatures describe that even if women's formal participation in the highest leadership position was formally closed, it is documented that throughout the world, women had played critical roles in times of wars and peace as community organizers and activists. Above all, for instance, un Ethiopian Women history, contributions and brilliant leadership role which have Emperor Minilik's (1877-1913) first formal wife, Bafena and second legal wife Empress Taitu had played is unforgettable history and comes first when one talk about Ethiopian women contributions. For instance, Taitu was acted as the chief advisor of Emperor with particular influence in the area of foreign relations. She holds high profile in the history for patriotism and uncompromisingly pursuing Ethiopia's independence (Meaza, 2009). These historical facts make it clear that despite their strengths, contributions and demonstrated leadership abilities, it has never been easy for Ethiopian women to ascend to formal political power (ibid.).

Now a day the FDRE government has adopted various enhancing instruments to promote equal participation of women in every subject of the nation's decision making positions among which the FDRE constitution is the most promising and binding one which had ever been existed in the history of the country. However some efforts have been made still the participation of women in leadership and decision making position is minimal as per to their counterparts. This can be evidenced with many aspects however, looking at proportion of women in the parliament which is entitled to be the highest policy making body of the nation, though it may seem increasing from time to time, it is still minimal, according to the information gained from international Parliament Union (IPU), in 2005 National election women accounts $21.3 \%$, where as in 2010 national election, their number has increased to $152(27.8 \%)$ out of the total 547 seats of HPR members, with compared to Rwanda (56.3\%), and South Africa of which they accounts for $44.5 \%$ and others (http://www.ipu.org//wmn-e/classif.htm). 


\section{Data Presentation, Analysis and InTERPREtation}

In this chapter data gathered from both primary and secondary sources through questionnaires and interview and document analysis is presented, analyzed, and interpreted in relation to basic research questions and the main research objectives stated so far.

Data collected through questionnaire is analyzed by using descriptive statistical tools such as graphs, tables, figures and charts and then interpreted qualitatively and quantitatively. Those data gathered trough interview from women affair office and mayor of Bedele town administration had been analyzed using description of findings.

Questionnaires had contained both closed and open ended questions were used to gather data from target group which are selected from the total population of civil servants in Bedele Town Administration using systematic sampling methods. Formal interview which is semi structured had been carried out with Mayor of Bedele Town and Women Affair Office. To achieve all these, a total of 108 questionnaires were distributed and 103 of them had filled by respected respondents and returned as well used for the purpose of the paper.

\section{BACKGROUND OF SAMPLE RESPONDENTS}

\section{Sex Composition of Sample Respondent}

Fia. 1 Sex comoosition of Samole resoondents $n=103$

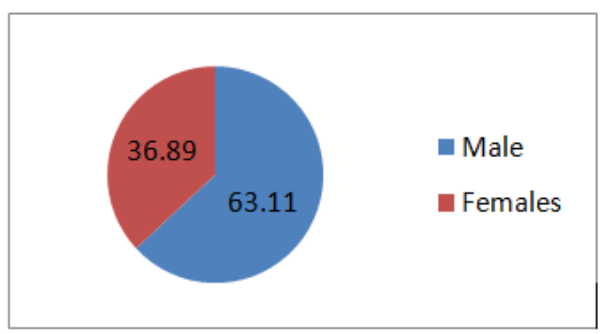

Fig. 2 Sex composition of civil servant of Bedele Town Administration $n=357$ (total civil servants in the town)

Source: Field Survey (May. 2012).

Source: Bedele Town Civil Service and Good Governance Office

With regard to sex composition of sample respondents as to the finding of the study indicated in the above fig. 1 and 2 above, while 65(63.11\%) of them are male the rest $38(36.895)$ of them are females. In addition to this the data gained from Bedele town civil service and good governance office also indicated that of total 357 employees (civil servants) of the town, 227(63.59\%), and 130(36.41\%) of them are men and women respectively. From this data, it can clearly be understood that the majority of civil servants are male and the enrollment of their counterpart is lower in public organization.

\section{Age Status}

Table 1 Age categories of sample respondents

\begin{tabular}{|l|l|c|c|}
\hline \multirow{2}{*}{ No. } & \multirow{2}{*}{ Age category } & \multicolumn{2}{|c|}{ Frequency } \\
\cline { 3 - 4 } & & In number & In $\%$ \\
\hline 1 & $\leq 20$ years & 3 & 2.91 \\
\hline 2 & $20-29$ years & 36 & 34.95 \\
\hline 3 & $30-39$ years & 32 & 31.07 \\
\hline 4 & $40-49$ years & 30 & 29.13 \\
\hline 5 & 50 and above & 2 & 1.94 \\
\hline & Total & $\mathbf{1 0 3}$ & $\mathbf{1 0 0}$ \\
\hline
\end{tabular}

Source: Field Survey (May. 2012). 
As it can be seen from table 1 above, age composition of total 103 sample respondents, while $3(2.91 \%), 36(34.95 \%)$ and $32(31.07 \%)$ of them have replied as their age is within less or equal to 20 years, between 20 and 29 , and 30 and 39 categories respectively, the rest $30(29.13 \%)$ and $2(1.94 \%)$ of them are categorized under age group of 40 to 49 and above or equal to 50 years respectively. as findings of analysis indicated, the majority of sample respondents are aged between a category of 20-49 years.

\section{Marital Status of Respondents}

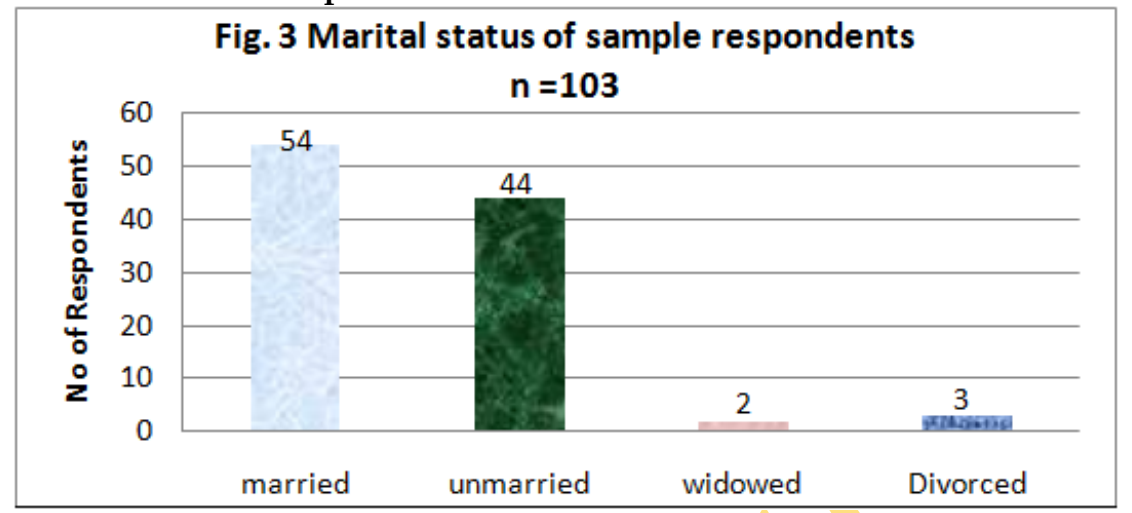

Source: Field Survey (May. 2012).

As can be inferred from figure 3 above, of total 103 sample respondents, 54(52.43\%), $44(42.72 \%)$ and $3(2.9 \%)$ of them are married, unmarried and divorced respectively. The rest $2(1.94 \%)$ of them are widowed. From all total women respondents, $34(89.47 \%)$, $3(7.89 \%) 1(2.63 \%)$ of them are married, single and widowed respectively. From this data it can be clearly understood that the majority of women are holders double responsibility that of family and their organizational activities.

Current Position of Respondents in their respected organizations

Fig. 4 Current position of sample respondents $n=103$

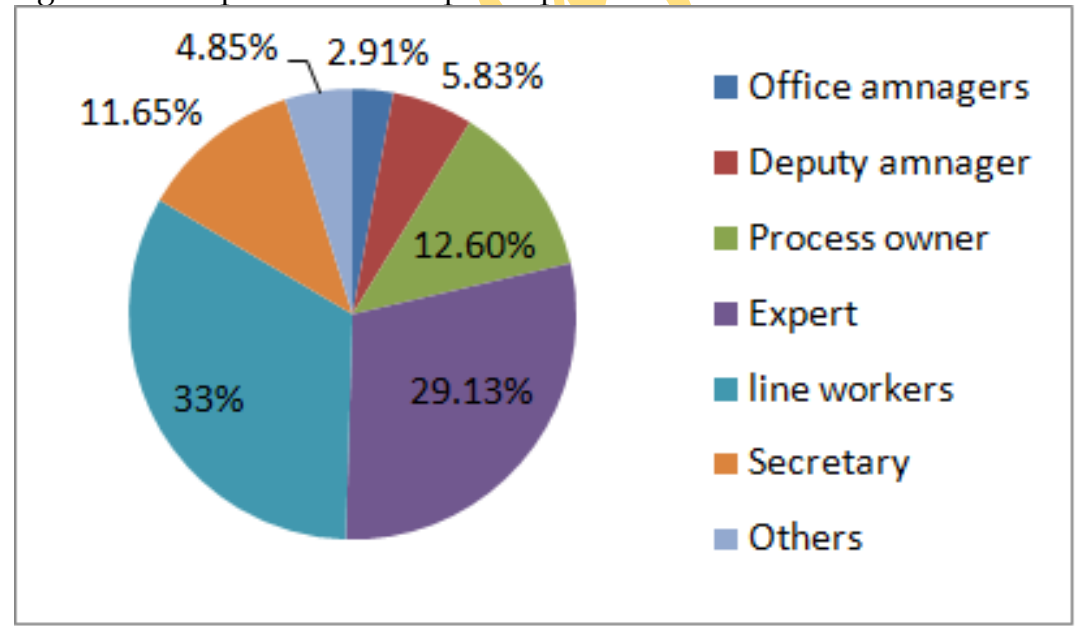

Source: Field Survey (May. 2012). 
As it has been indicated on figure 4 above, total 103 respondents who had responded to the questionnaires, while $3(2.91 \%), 6(5.83 \%), 13(12.6 \%)$ of them are office manager, deputy manager and process owner respectively, others $30(29.13 \%), 34(33 \%)$ and $12(11.65 \%)$ of them are replied as they are an expert, line worker and secretary respectively, finally the rest $5(4.85 \%)$ of them replied as other s (cashier, manual worker, etc).

Of total women respondents, while $5(13.16 \%)$ of them are holders of relatively higher decision making positions such as organizational head, deputy, and department head, the rest $33(86.84 \%)$ of them are holders of non decision making position such as line workers, experts, secretary, cashier and manual workers. From this data, one can understand that though the existing various legal documents (rules, regulations, and laws etc) states the importance of encouraging and empowerment as well as participation of women in public leadership and decision making positions, the reality has shown the opposite

\section{Work Experience of Respondents}

With regard to service year information of respondents as indicated in the following table 2 , of total sample respondents $29(28.15 \%), 15(14.56 \%)$, and $19(18.45 \%)$ of them had responded as they have a work experiences of less than 5 years, 5 to 10 and 11 to 15 years respectively. similarly, the rest $14(13.59 \%), 10(9.7 \%)$, and $16(15.53 \%) 16$ to 20 years, 21 to 25 years and above 25 years respectively.

Table 2 Respondents work experiences

\begin{tabular}{|l|l|l|l|}
\hline S.N. & \multirow{2}{*}{ Work experience category } & \multicolumn{2}{|l|}{ Frequency } \\
\cline { 3 - 4 } & & In number & In $\%$ \\
\hline 1 & $\leq 5$ years & 28 & 28.15 \\
\hline 2 & $5-10$ years & 15 & 14.56 \\
\hline 3 & $11-15$ years & 19 & 18.45 \\
\hline 4 & $16-20$ years & 14 & 13.59 \\
\hline 5 & $21-25$ years & 10 & 9.7 \\
\hline 6 & Above 25 years & 16 & 15.53 \\
\hline & Total & $\mathbf{1 0 3}$ & $\mathbf{1 0 0}$ \\
\hline
\end{tabular}

Source: Field Survey (May. 2012).

This data clearly shows that the majority (about 71.84\%) of total respondents had sufficient work experiences (i.e. at least five years and above) and is therefore assumed that they are able to provide adequate and sufficient information about the factors that affect women participation in public leadership and decision making positions with respect to public institutions.

\section{Educational Status of Sample Respondents}

As it has been shown in the following Fig.5, which shows educational status of sample respondents, while the educational status of $4.85 \%, 10.68 \%$ and $64.07 \%$ of them belongs to below certificate, certificate, and diploma respectively, the rest $19.42 \%$ and $0.97 \%$ of them are holders of 1 st degree and 2nd degree respectively. Hence from this data, one can simply observe that the majority (about $84.47 \%$ ) of total respondents have an educational status of at least diploma and more. Further, it can also be said that sample respondents are more qualified to express about factors that hinder women from public decision making and related issues. 


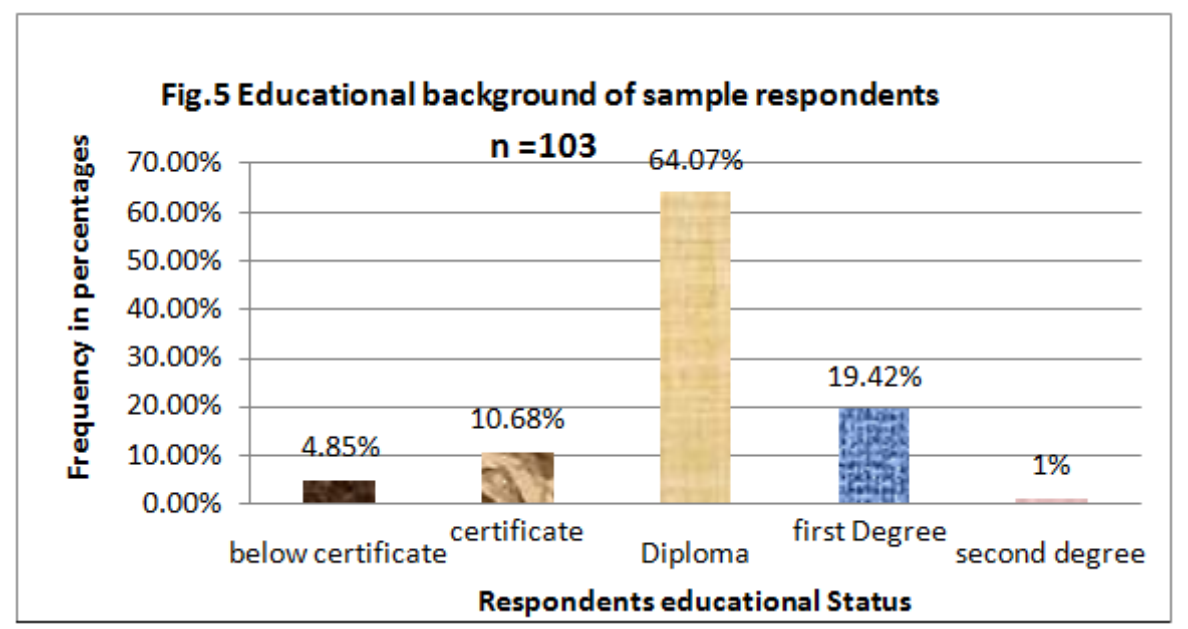

Source: Field Survey (May. 2012).

\section{Women In DECISION MAKING Positions}

\section{Positions Occupied by Women in public Organizations}

Table 3 Positions occupied by women

\begin{tabular}{|c|c|c|c|c|}
\hline \multirow[b]{2}{*}{ S.N. } & \multirow[b]{2}{*}{ Position held } & \multicolumn{2}{|l|}{ Frequency } & \multirow[b]{2}{*}{ Description } \\
\hline & & In number & In $\%$ & \\
\hline 1 & Organization head & 13 & 12.62 & \multirow{7}{*}{$\begin{array}{l}\text { Multiple answers were possible } \\
\text { ( a respondent was free to choose } \\
\text { more than one option) }\end{array}$} \\
\hline 2 & Vice organization head & 22 & 21.36 & \\
\hline 3 & Process owner (line worker) & 70 & 67.96 & \\
\hline 4 & Clerical worker & 89 & 86.41 & \\
\hline 5 & Manual routine worker & 83 & 80.58 & \\
\hline 6 & Committee member & 41 & 39.8 & \\
\hline 7 & Other & 5 & 4.85 & \\
\hline
\end{tabular}

Source: Field Survey (May. 2012).

As it has been indicated in table 3 above, respondents have pointed out the positions occupied by women in their respected organizations. Accordingly, $12.62 \%, 21.36 \%$ and $67.96 \%$ of sample respondents indicated that in their organization, women are assigned as office manager (CEO), deputy manager and process owner (line worker), respectively. Similarly, $86.41 \%, 80.58 \%$ and $39.8 \%$ of them mentioned as women are assigned as clerical worker and routine worker, manual worker, and committee member positions respectively in their organizations, further, $4.85 \%$ of respondents had pointed that women are hold some other positions. This data clearly shows that though respondents were free to indicated more than one positions where women are assigned, the majority, $86.41 \%$ and $80.58 \%$, and $67.96 \%$ of them indicated as women posted on clerical worker, manual worker and process owner (line worker) positions respectively. Contrary to this, only, $12.6 \%$ and $21.36 \%$ of them replied women's positions as office manager and deputy manager positions of their organization are occupied by women. This data also confirms the fact that has been revealed by various early researchers.

Taking in to account data gained from Bedele town government communication, out of total 35 public institutions leadership and decision making positions (20 managers and 15 deputy manager positions), women are only accounted for $9(25.71 \%)$ : (3(15\%) of managers and $6(40 \%)$ 
of deputy managers) and the rest $74.29 \%$ are occupied by their counter parts. Therefore even though various policies, strategies have been developed and ratified to bring equal distribution of power between men and women $\mathrm{n}$ public decision making affairs, at least in black and white before a decade, still the practice observed is far from intended aspect.

\section{Emphasis given for women in respected public organization}

In the organization you are currently working in which of the following tasks, the participation of worker given more emphasis?

Table 4 Emphasis given for women

\begin{tabular}{|c|c|c|c|c|}
\hline \multirow[b]{2}{*}{ S.N. } & \multirow[b]{2}{*}{ Position held } & \multicolumn{2}{|l|}{ Frequency } & \multirow[b]{2}{*}{ Description } \\
\hline & & In number & In \% & \\
\hline 1 & Decision making & 17 & 16.5 & \multirow{5}{*}{$\begin{array}{l}\text { Multiple answers } \\
\text { were possible } \\
\text { ( a respondent was free } \\
\text { to choose more than one } \\
\text { option) }\end{array}$} \\
\hline 2 & Leadership & 14 & 13.59 & \\
\hline 3 & Routine manual and clerical work & 72 & 69.9 & \\
\hline 4 & Planning and controlling & 58 & 56.31 & \\
\hline 5 & Other & 6 & 5.82 & \\
\hline
\end{tabular}

Source: Field Survey (May. 2012).

As it has been indicated in table 4, which shows the general area given emphasis for assignment of women in organizations, $17(16.5 \%), 14(13.59 \%)$ and $72(69.9 \%)$ of respondents indicated as women in their organization are more often assigned in the areas of decision making, leadership, routine manual and clerical work, respectively. Similarly $58(56.31 \%)$ and $6(5.82 \%)$ of respondents indicated as women in their organization are assigned largely in planning and controlling as well as other areas respectively.

In the interview with Mayor and Head of Women Affair Office, both have stated that though the participation of women in public decision making and leadership position has been increased as it was expected due to various reasons, currently (after few years) due attention is being given through government programs and have been somewhat increased and can be sought encouraging.

This data clearly show that even though the higher officials has perceived as relatively increased, as the majority of respondents pointed out, more emphasis has been given for assignment of women in organizations with in Bedele town has given in the areas of routine manual work and clerical work and planning and controlling areas. Surprisingly, women in leadership making-areas are kept far away

\section{Respondents' attitude towards women's successfulness}

Do you think that women are successful (achieve the objective of the organization) if they are provided a leadership position as to their counterparts?

Table 5 Respondents attitude towards women's successfulness in leadership roles

\begin{tabular}{|l|l|c|c|}
\hline \multirow{2}{*}{ S.N. } & \multirow{2}{*}{ Item } & \multicolumn{2}{|c|}{ Frequency } \\
\cline { 3 - 4 } & Yes & In number & In \% \\
\hline 1 & No & 93 & 90.29 \\
\hline 3 & No comment & 3 & 6.8 \\
\hline & Total & $\mathbf{1 0 3}$ & $\mathbf{1 0 0}$ \\
\hline
\end{tabular}

Source: Field Survey (May. 2012). 
As it is can be seen from table 5 above, while $93(92.29 \%)$ of sample respondents replied as women would be successful if they are provided leadership positions. With regard to the successfulness of women in public decision making and leadership position, pointed that if conditions are set favorably and enabling and capacitating programs are implemented, not only they are successful as that of their counter parts, even they can exceed that of men. Moreover, he has stated as women are intelligent and systematic in solving problems but denied to obtain chances.

Others 7(6.8\%) of them are responded as women would not be successful in leadership and decision making professions as to their counterparts. As to these respondents (whom said 'No'), argued women fail in leadership positions due to the fact that the position needs high energetic and high influencing power (ability) up on their followers. However, women lack experiences and are bounded heavy domestic work and can't control all over leadership and decision-making roles. On the other hand $3(2.9 \%)$ of total respondents had kept their view neutral. These respondents has also put their reason viewing as it is difficult to conclude all females can be successful or not with regard to leadership and decision making because some may be successful and others may fail.

Factors hindering women from leadership and decision making positions

As it can be seen from the following figure 6, while $71(68.93 \%)$ of total respondents confirm that women were not fairly represented in leadership and decision making positions, the rest $32(31.07 \%)$ of them said women are adequately, represented in leadership and public decision making positions. From this data, it can be clearly seen (understood) that the majority of sample respondents viewed that women are not fairly represented in public leadership and their participation in public decision making area is low.

Do you think that women are represented comparatively as to their share in total population in leadership and decision making positions?

Fig 6 Respondents view about women representations in public leadership and decision making

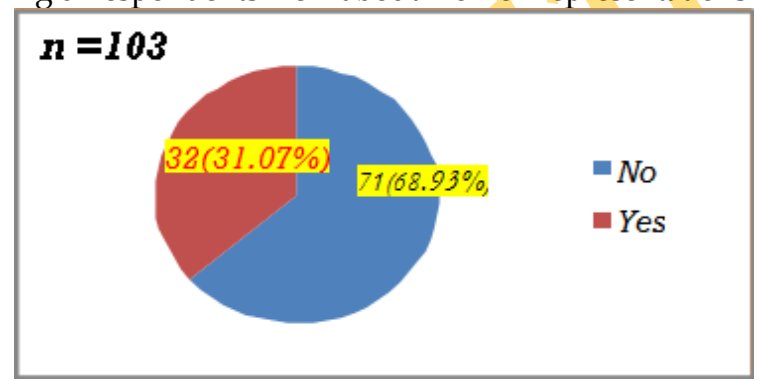

Source: Field Survey (May. 2012)

On the other hand, sample respondents who said "No women are not adequately represented" had asked to point out major factors that has made obstacles to women to so as to hold public leadership and decision making positions.

Accordingly, as it has been indicated in the following table 6, of those said "No", while $55 \%, 22.54 \%$ and $64.8 \%$ of total respondents pointed out lack of sufficient education, skill and absence of enabling environment to hold public decision making respectively as an obstacle to women, others, $14.08 \%, 85.92 \%$ and $22.54 \%$ of them mentioned religious factor, socio-cultural attitude towards women, legal (such as procedures, directives etc) barriers, as major obstacle. 
Table 6 Respondents View about the Main Factors hindering women from leadership and decision making position

\begin{tabular}{|c|c|c|c|c|}
\hline \multirow[t]{2}{*}{ S.N. } & \multirow[t]{2}{*}{ Factors (Item) } & \multicolumn{2}{|c|}{ Frequency } & \multirow[b]{2}{*}{ Description } \\
\hline & & In No. & In $\%$ & \\
\hline 1 & Lack of adequate education & 39 & 55 & \multirow{11}{*}{$\begin{array}{l}\text { Multiple answers } \\
\text { were possible } \\
\text { (a respondent } \\
\text { Was free to choose } \\
\text { more than one option) }\end{array}$} \\
\hline 2 & lack of a dequate skill & 16 & 22.54 & \\
\hline 3 & Absence of enabling environment (commitment) by concemed bodies & 46 & 64.8 & \\
\hline 4 & Religious factors & 10 & 14.08 & \\
\hline 5 & Socio-cultural attitudes & 61 & 85.92 & \\
\hline 6 & Legal bamiers & 16 & 22.54 & \\
\hline 7 & lack of a dequate service year required & 48 & 67.61 & \\
\hline 8 & Attitude (lack of confidence and willingness) of women by themselves & 27 & 38.03 & \\
\hline 9 & Over burden of domestic responsibilities & 57 & 80.28 & \\
\hline 10 & Attitude (negative) of men towards women & 56 & 78.87 & \\
\hline 11 & Other & 9 & 12.68 & \\
\hline
\end{tabular}

Source: Field Survey (May. 2012)

Similarly, $67.61 \%, 38.03 \%$ and $80.28 \%$ of those said women are not fairly represented indicated lack of adequate service year required to hold decision making and leadership positions, overburden of domestic responsibilities, attitude of women themselves to hold public decision making and leadership position, respectively as major factor that has hindered women to hold public leadership and decision making. Finally, 78.87\%, 12.68\% of them marked negative attitude of men towards women and other factors respondents mentioned; such as absence which has the significant number of respondents mentioned; such as absence of Women role models in the local areas for girls and women at large, are the major factor that has hindered women from public leadership positions.

If we specifically consider the educational status of all women civil servants in Bedele town on the basis of data gained from Town Administration government Communication office, of total degree and diploma holders of 212 employees, women are accounted only for $39 \%$ ( $13.64 \%$ of degree holders and $45.8 \%$ of diploma holders). Hence, even though the participation of women in formal public institution constitute $36 \%$ of total 357 employees, it can be said that women are not marginalized from participation in formal public career, but also from access of higher educational levels, which makes them competent to hold in higher organizational positions.

Similarly, with the issue under consideration, officials interviewed have also confirmed stating the main factors (barriers) affecting from leadership positions as low level of commitment and confidence by women themselves to fight violence against them, prevalence of traditionally harmful backward attitude (outlook) in the society towards women, lack of role model women in the locality and others are some can be stated.

This data clearly indicates that as the majority of sample respondents confirmed, the major factor that has hindered women from leadership and public decision making are: lack of adequate education, absence of enabling environment, by concerned bodies, patriarchically rooted (male dominated) socio-cultural attitudes(outlooks), lack of sufficient work experiences required to hold the position, absence of confidence (negative attitude) of women to hold public leadership by themselves and negative attitude of men towards women to hold public leadership. Though factors that hinder women from leadership and decision making positions are multi-factor and vary from culture to culture, it is underlined by almost all respondents is that absence of willingness of women themselves and their educational background take the lion share of the factors. 


\section{Share of Domestic Responsibilities between Men and Women}

Table 7 Men/women share of domestic responsibility

\begin{tabular}{|l|l|l|l|}
\hline & & \multicolumn{2}{|l|}{ Frequency } \\
\cline { 3 - 4 } S.N. & \multirow{2}{*}{ Factors (Item) } & In No. & In \% \\
\hline 1 & Women & 98 & 95.15 \\
\hline 2 & Men & 5 & 4.85 \\
\hline & Total & $\mathbf{1 0 3}$ & $\mathbf{1 0 0}$ \\
\hline
\end{tabular}

Source: Field Survey (May. 2012)

All of the respondents were asked as whom will stay home and solve probably if a problem has occurred in domestic (e.g. if a child felt unhealthy (get sick) etc)). Accordingly, as it can be inferred from table 7 above, surprisingly, $95.15 \%$ of all sample respondents replied as women and only the rest $4.85 \%$ said men. This data shows that, Women are still facing a lot of challenges related to social and cultural pressures. The perceived traditional roles of men and women have not changed in relation to daily practice. The working environment for women is still unfriendly at both working and societal levels due to gender stereotypes and patriarchal structures. Women leaders and professionals are still faced with traditional roles and also have to meet work/professional expectations. Neither their husbands nor their male relatives have give way to the changes conduct in by the era of gender equality promotion. For women to be able to perform on an equal footing with men, they have to walk extra miles. As a result, women are heavily over burdened with domestic responsibilities, and much of their time is consumed doing home based responsibilities than public oriented responsibilities. This also implies that men psychological orientation to hold and solve domestic responsibilities and activities is sought to be very significantly low. Moreover, it can be argued that among many practical(real) barriers facing those women who wish to take a more active role in the political and public decision making, economic and civil society sectors is lack of time.

Too, it is also observed that there is a strong male bias in the work culture of organizations, many of which favor leaders who have a traditional 'male' role in family life over those who carry out unpaid caring work. This places women at a distinct disadvantage, expected them to undertake the bulk of domestic and child care work; as these caring responsibilities extend to collect fuel and water, growing food to feed their families.

\section{Awareness about National Women Policy}

A policy formulated by the existing (FDRE) government is expected to play a significant role in facilitating, conditions to speeding up of equality between men and women in order to let women participate in the social, economic and political life their country in equal terms with that of men. Women's roles and participation in decision making positions and their enjoyment of their fruits and benefits of development on equal basis with men were emphasized in the content of the national policy. Therefore, all of the community (at least, civil servants) are required to be aware of the policy in order to bring stated objective in to reality. Accordingly, respondents were asked about their awareness about the contents of it as follows:

Do you know the contents of FDRE National women policy? 
Table 8 Sample respondents about FDRE national policy

\begin{tabular}{|l|l|l|}
\hline \multirow{2}{*}{ Items } & \multicolumn{2}{|l|}{ Frequency } \\
\cline { 2 - 3 } & In No. & In $\mathbf{0}$ \\
\hline Yes & 49 & 47.57 \\
\hline No & 54 & 52.43 \\
\hline Total & $\mathbf{1 0 3}$ & $\mathbf{1 0 0}$ \\
\hline
\end{tabular}

Source: Field Survey (May. 2012).

As it has been shown in table 8 above, with regard to awareness and knowledge about contents and concerns of FDRE national women policy, while $49(47.57 \%)$ of sample respondents has replied as they read and know the contents and concerns of FDRE national women policy, the rest $54(52.43 \%)$ said they had never read and do not know the major concerns and contents of national women policy of 1993.

With regard to creating awareness towards the public about national women policy, the women affair office responded as some efforts have been carried out, like preparing and distributing flyers (broachers), duplicating (photocopying )the policy paper and distributing to public institutions, preparing discussion sessions with civil servants about the policy, and so on. In general even most call of government efforts and are being carried out to enhance and capital women participation in all spheres of socio-political and economical dimensions it is surprising that most of sample respondents replied as they had never read national women policy.

Other than National Women Policy(NWP), do you think that other development policies are women friendly and encourages women participation in leadership and decision making positions? What are their manifestations?

Table 9 Respondents view about women friendliness of other Government policies than NWP

\begin{tabular}{|c|c|c|c|}
\hline \multirow[b]{2}{*}{ S.N. } & \multirow[b]{2}{*}{ Item } & \multicolumn{2}{|l|}{ Frequency } \\
\hline & & In number & In $\%$ \\
\hline 1 & Yes & 72 & 69.9 \\
\hline 2 & No & 17 & 16.5 \\
\hline 3 & No comment & 14 & 13.6 \\
\hline & Total & 103 & 100 \\
\hline
\end{tabular}

Source: Field Survey (May. 2012).

As can be observed from table 9 above, with regard to women friendliness of FDRE development policies of other than women national policy, 72(69.9\%), 17(16.5\%) and $14(13.6 \%)$ of sample respondents viewed "yes", "No" and "No comment" respectively to the issue.

Those who has viewed friendliness of government development policies, pointed out that every social and development oriented policies of the existing government are first examined and assessed as if they address the needs and interests of those marginalized groups and are required to qualitatively and quantitatively indicate specifically from the point of women empowerments.

Further, they said that, all of government (either Federal or Regional) policies are interrelated and do not contradict each other. In addition, they has mentioned that every government polices do emerge from FDRE constitution and hence required to address constitutionally stated issues accordingly. 


\section{SUMMARY OF FINDINGS}

Based on data analysis, the following major findings have been drawn.

- With respect to marital status of sample respondents, it is revealed that 52.43 and $42.72 \%$ of them are married and unmarried respectively.

- It is observed that the majority of civil servants in Bedele town administration are accounted to be male. This implies that, the involvement of women in public institution is seen low. Out of total $76.32 \%$ of them are posted in the lower non decision making position, and the rest $23.68 \%$ of them are relatively in higher decision making positions (of which $7.89 \%$ are office managers and deputy mangers, and $15.79 \%$ are department heads). Furthermore, it is observed that none of male are assigned in the positions such as secretary, and cashier.

- Data analysis has indicated that only $39 \%$ of total women civil servants in the town have an educational status of diploma and more educational levels.

- It is revealed that in Bedele town administration, for the assignment of women with in their respective public institution, the emphasis has been given in lower positions such as routine manual and clerical work and similar activities. But, as $90.29 \%$ of respondents pointed out that if favorable conditions are set and are accessed the positions of public leadership, they can successfully achieve organizational goals effectively. However, the majority $(68.93 \%)$ of total respondents indicated as women are underrepresented in public leadership and decision making positions.

- The finding showed that the major factors that hinder women's participation in public leadership and decision making positions are various and observed interrelated. These include: lack (absence of adequate) educational status required from women, absence of commitment by the concerned(top decision making) body, backward sociocultural attitudes, lack of sufficient experiences from women to hold the leading positions, overburden of domestic responsibilities, as well as negative attitudes of men towards women, and lack of confidence from women themselves.

- As the trend of initiating the participation of women in public leadership is relatively recent phenomenon, it is observed that women are not only disadvantaged with respect to participating in public leadership but also in attaining higher educational levels.

- It is revealed that, as one goes up in public organizational leadership decision making positions, the concentration of women decreases, where as the opposite becomes real in lower organizational levels; hence, women are underrepresented.

- It is observed that in Bedele town administration, the major upgrading schemes undertaken to capacitate women are: placement (delegation), participating in management committee, coaching, and providing rewards for best performers from women civil servants.

- $62.14 \%$ respondents showed that in the town administration, there are some efforts being carried out to make the public aware about the rights of women by the local administration in the town.

- As finding of the study revealed out, though there is comprehensively formulated national women policy and strategies so as to promote women participation in sociocultural, political, and economical arenas before a decade, still there is low awareness about the concerns of the documents among both sexes of civil servants in Bedele town administration.

- As to majority of respondents, while the participation of women in decision making positions of community based organizations such as 'Idir' is observed low, the 
encouragements made by political parties in the town administration for the participation of women in public leadership and decision making position is judged good by $78.65 \%$ of total sample respondents.

- As to $95.14 \%$ of respondents indicated, participating women in public leadership and decision making is not only an important issue for the development of the nation, it is mandatory and pre requisite for the prevalence of good governance as well as keeping basic human and political rights.

As the study indicated, women affair office in the town administration is being challenged to execute its mandates due to lack of adequate skilled manpower, lack of adequate budget allocation by the town administration, lack of clear enforcement mechanisms to implement affirmative actions uniformly across the public institutions, insufficient support by the concerned bodies, attitudinal problems on the parts of male colleagues and officials, lack of gender mainstreaming in various offices and the like.

\section{CONCLUSIONS}

Based on the findings of the study, the following conclusions have been drawn.

- In Bedele town administration the participation of women in higher public leadership and decision making positions as well as in community based organizations such as 'Idir' is observed low. Emphases are given for the assignment of women in lower positions such as: routine manual, clerical, and line worker. Lack of women's representation and participation has been attributed to several factors and constraints. Some of the constraints observed include organizational structures that inhibit women's participation, negative attitudes towards women's participation and the existing expectations of traditional and cultural roles for women. Furthermore, women's capacity to participate at leadership levels is restricted due to over burden of family responsibilities, cultural expectations and stereotyping that 'a woman's place is in the home'. As a result, it can be concluded that, if men alone are seen to be making decisions of public importance, then girls and boys, women and men can be led into believing that women have no legitimate place in such decision-making. This then has a self-fulfilling effect, meaning that girls and women do not see themselves as 'important' decision-makers and neither do men and boys; and men and boys are legitimated in 'keeping women and girls out' of decision-making positions.

- Women exclusion from political and public leadership and decision making structures and processes is observed as the result of multiple socio-cultural, individual, and institutional factors. As a result, women are denied their right over resources(economical resources, such as income generating skills, tools and opportunities; political resources such as representative organizations, education, public spheres experiences, self confidences and credibility; and time resources)

- It is concluded that women are not only kept away from higher leadership positions, but also from access to higher education which makes them develop skills, and capacitate them with managerial decision making techniques, help them develop confidence in holding leadership positions.

- The finding of the study indicated that the majority of respondents confirmed that if favorable conditions are set at place and women are provided the position to lead, they are as effective and successful as or more than that of their male counterparts. This indicates that there is some encouraging but needing strengthen attitudinal changes among civil servants in the town towards women's leadership and decision making. 
Women's exclusion from the decision-making processes in public decision making position should be an issue, which can no longer be ignored. If at one point people saw public leadership positions as a male domain, this alleged grounds can not be continued any longer. Democracy would be disrespect if half of the population of country were left out. In order to correct this imbalance, certain measures must be taken into account.

\section{BIBLIOGRAPHY}

African Training and Research Centre in Administration for Development Report Conference on Strengthening Women Capacities in Administration, Governance and Leadership Tangier (Morocco), on 23 - 25 March 2009.

Almaz E (1991). Perspectives on Gender and Development. In: Tsehai Berhane Selassie (Ed.) Gender Issues in Ethiopia. Institute of Ethiopian Studies. Addis Ababa University, Addis Ababa.

Bajdo, L. M., \& Dickson, M. W. (2001). Perceptions of organizational culture and women's advancement in organizations: A cross-cultural examination. Sex Roles, 45(5/6), 99.

Batliwala,Srilata (1993). Defining Women's Empowerment: A Conceptual Framework, www.genderatwork.org/updir/Batliwala-empowermentframework.htm,( retrieved on October,04,2010)

Bolman, L. G., Terrence E. (1997). “Deal Reframing organizations”, Jossey-Bass Publishers, p. 295.

Byers, P.Y. (1997). “Organizational Communication”, Allyn \& Bacon, Boston, p. 118.

CEDAW (1979).http// www.un.org/womenwatch/daw/cedaw/cedaw.htm ( last accessed December 2010)

CSA (2004). Urban Bi-Annual Employment Unemployment Survey, Addis Ababa.

CSA (2008). Summary and Statistical Report $\mathrm{f}$ the 2007 Population and Housing Census: Population size by age and Sex. Addis Ababa.

Dimtsachin (April-June, 2004). A quarterly magazine of Ethiopian Lawyer Association. Addis Ababa

Dimtsachin A Quarterly Magazine (2004). Ethiopian Lawyer Association December, 2004.

Erez, M., \& Gati, E. (2004). A dynamic, multi-level model of culture: From the micro level of the individual to the macro level of a global culture. Applied Psychology: An International Review, 53(4), 583-598.

Ethiopian Society of Population Studies (2008). Gender Inequality and Women's Empowerment: Indepth Analysis of the Ethiopian Demographic and Health Survey 2005, Addis Ababa.

Fagerberg, J. (1994). Technology and international differences in growth rates. Journal of Economic Literature, 32, 1147-1175.

Farid, M. (2007). Entrepreneurship in Egypt and the US compared: Directions for further research suggested. The Journal of Management Development, 26(5), 428.

FDRE (1994). FDRE Education and Training Policy. Addis Ababa: St. George Printing Press.

FDRE (1997). FDRE Cultural Policy. Addis Ababa: Artistic Printing Press.

FDRE_ (1995). FDRE Constitution. Addis Ababa: Berhanena Selam Printing Enterprise.

Federal Civil Service Commission (2005). Survey on the Status of Men and Women Employees and Strategies for Gender Equality. Main Report. Addis Ababa.

Fourth World Conference on Women (FWCW) Platform for Action (1995). Women in Power and Decision -Making, www.un.org/womenwatch/daw/ beijing/platform/decision/

Gardner, J. W. (1990). “On Leadership”, The Free Press, New York, p. 171 (p. 9).

Haregewoin C, Emebet M (2003). Towards Gender equality in Ethiopia. A Profile of Gender Relations. Swedish International Development Cooperation Agency.

Hirut T (2004). Violence Against Women in Ethiopia: A Strong Case of Civil Society Concern. In: Chowdhury, S., Wais, A., and Kahsai Wolde Giorgis (Eds) Civil Society in Ethiopia: Reflections on Realities and Perspectives of Hope. African - Asian Studies Promotion Association.

http:// publications.oxfam.org.uk/oxfam/display.asp?ISBN=9780855986261(Women's Leadership and Participation: Overview, Women's Leadership \& Participation, Programme Insights, Oxfam GB. February 2008 18)

http://www.ipu.org//wmn-e/classif.htm (Women in Politics 60 Years in retrospect information Kit, IPU. November 12,2010 
http://www.womenscampaigninternational.org (proposed Curriculum for the capacity building training with women members of parliament of the house of people's Representatives of Ethiopia, last accessed on January , 22,2011)

Human Development Report (1993). United Nations Development Programs. New York: UNDP.

Jane H. Bayes and Jeane Mariecol (1991). Women and public Administration an international Perspective. USA, New York, Harrington Park Press.

Jelaludin A, Abgeli A, Alemtsehay B, Salvini S (2001). Gender Issues, Population and Development in Ethiopia: in-depth Studies from the 1994 Population and Housing Census in Ethiopia Central Statistical Authority, Addis Ababa, and Institute for Population Research - National Research Council (Irp - Cnr), Roma.

Joshi ST (1999). Women and development - The changing scenario. New Delhi: Mittal Publications.

K., Leung \& Bond, M. H. (2004). Social axioms: A model for social beliefs in multicultural perspective. In M. P. Zanna (Ed.), Advances in experimental social psychology (Vol. 36, pp. 119-197). San Diego, CA: Elsevier Academic Press.

Khan, Niaz Ahmed (1993). “Towards an Understanding of 'Participation'; The Conceptual Labyrinth Revisited" in Administrative Change, Vol.XX, Nos.1-2: July 1992-June, pp.106-120.

Kouzes, J. M., Posner, B. Z. (1995). “The Leadership Challenge”, Jossey-Bass Publishers, San Francisco, p. 29.

Lieb, H., \& Thistle, S. (2005). Marriage, work, poverty, and children: The changing impact of marriage, motherhood and work on women's poverty. Journal of Women, Politics \& Policy 27(3/4), 5.

March C, Smyth I, Mukhopadhyay M (1999). A Guide to Gender Analysis Frameworks. Oxfam Print Unit.

Matlsoa k. and shale M. (2008). Political Parties Programme Handbook ETSA, Johannesburg South Africa

Meaza Ashenafi (2009). Factors Affecting Women Participation in Politics and Decision making. A Dissertation of MA Thesis

Meron Genene (2003). http://131.130.59.105:8180/ethiopia/pdf/speech_meron.pdf (last accessed on January 22,2011) Paper presented at the conference entitled "Bridge Building between Ethiopia and Austria", organised by Äthiopisch-Österreichische Frauensolidarität and ÖsterreichischÄthiopische Gesellschaft, May 9, 2003, Vienna, Austria.

Misra, S.N. (1984). Participation and Development, India: NBO Publishers.

Mukuria A, Aboulfia C, Themme A (2005). The Context of Women's Health: Results from the Demographic and Health Surveys, 1994 - 2001. Comparative Reports No 11. Calverton, Maryland: ORC Macro.

National Committee Traditional Practices in Ethiopia (2003). AAU Printing Press, Addis Ababa.

Oxaal, Zoe and Baden, Sally (1997). Gender and Empowerment: Definitions, Approaches and Implications for Policy, Bridge (development-gender). University of Sussex: Institute of Development Studies. UK.

Rahman, M. Shamsur (1991). People's Participation at the Upazilla Level: Problems and Prospects (A Study of Twelve Upazillas in Bangladesh), Rajshahi University.

Sen S, Batliwala S (2000). Empowering women for reproductive rights. In: Women's empowerment and demographic processes, Harriet B. and Gita Sen Presser. New York: Oxford University Press.

Sharma, S. (2007). Financial development and innovation in small firms The World Bank.

Sosena Demissie and Tsehai Yitbarek (2008). Digest of Ethiopia's Policies, Programs and Strategies: A Review of National Policy on Ethiopian Women, EEA, Addis Ababa.

Stelter, N. Z. (2002). Gender differences in leadership: Current social issues and future organizational implications. Journal of Leadership \& Organizational Studies, 8(4), 88.

T., Friedman (2005). The world is flat. New York: Farrar, Straus, and Giroux.

Tesfu Baraki (1996). Society and Women in Ethiopia, EWLA sponsored Research. Addis Ababa, Unpublished.

TGE (1993). National Population Policy of Ethiopia. Office of the Prime Minister. Addis Ababa.

Tigist Zeleke (2005)sss. The Political Participation of Women in Ethiopia: Challenges and Prospects. EWLA, Addis Ababa.

UN (1995). The World's Women Trends and Statistics. USA, New, United Nations Publication

UN. (2005b). Investment in development: A practical plan to achieve the millennium development goals. New York: United Nations Development Programme. 
UNDP (2003). Empowering Women the Key to Achieving the Millennium Development Goal.

UNDP. (2007). Making globalization work for all: United nations development programme annual report 2007. New York: United Nations Development Programme

Wikipedia (2005). 22nd July .http:/ / en.wikipedia.org/wiki/women, Retrieved on 24.07.2005.

World Bank. (2007b). Doing business report 2008: Comparing regulations in 178 economies. Washington, D.C.

World Bank. (2008a). Enterprise Survey. Retrieved January/February 2008, from www.enterprisesurveys.org

World Bank. (2008b). Paying taxes 2008: The global picture. Washington, D.C.: The World Bank / Price Waterhouse Coopers.

Yukl, G., (1994). “Leadership in Organizations”, Prentice Hall, New Jersey, p. 3.

This article is is licensed under a Creative Commons AttributionNonCommercial 4.0 International License. Attribution-NonCommercial (CC BYNC) license lets others remix, tweak, and build upon work non-commercially, and although the new works must also acknowledge \& be non-commercial.

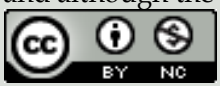

How to Cite: Hora EA. 2014. Factors that affect Women Participation in Leadership and Decision Making Position Asian Journal of Humanity, Art and Literature, 1, 97-117. 


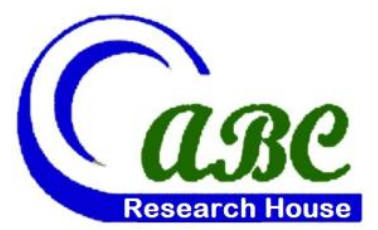

- Off Pantai Dalam, Kuala Lampur, Malaysia

- Road \# 4, Shyamoli, Dhaka-1207, Bangladesh

- 3900 Woodhue Place, Alexandria, VA 22309, USA

www.abcreorg.weebly.com / www.abcjournals.net

Asian Business Consortium (ABC) is a multi-disciplinary research, training, publishing, digital library supporting and service house. Though founded in 2010 as the Business and Computing organization of Asia, it was reconstituted as the ABC in 2011. It has been working for creating and nurturing talents in USA, Malaysia and Bangladesh since its inception. The objectives of consortium are solely centered round the welfare and humane attitude of the founders who enthusiastically took up this noble cause and materialized it with a view to promote research and educational activities for the encouragement of scholars to develop their knowledge, to publish their analysis oriented scientific researches in international Journals, books, the task of organizing workshops, seminars, conferences, training, personality development programs and allied services.

In addition to research activities, $A B C$ provides a good number of scholarships to the poor and meritorious students at various levels of education throughout the world. It plays an important role in the field of research by funding research projects and publishing the research papers. This consortium will unquestionably become the mouth-piece of the dark horses and unacknowledged scholar whose endowed and commendable contributions shall be provided an outlet keeping in mind the greater good of the larger society of the world.

$\mathrm{ABC}$ runs the following international referred journals for creating a platform to share the thoughts of professionals, scholars and academicians throughout the world.

\section{ABC Publications (ABC Journals)}

- Asian Accounting and Auditing Advancement (4A Journal)

- Asian Business Review (ABR)

- Asian Journal of Applied Sciences and Engineering (AJASE)

- Global Disclosure of Economics and Business (GDEB)

- $\quad$ ABC Journal of Advanced Research (ABC-JAR)

- International Journal of Reciprocal Symmetry and Theoretical Physics (IJRSTP)

- American Journal of Trade and Policy (AJTP)

- Asian Journal of Humanity, Art and Literature (AJHAL)

- Malaysian Journal of Medical and Biological Research (MJMBR)

- $\quad$ Asia Pacific Journal of Energy and Environment (APJEE)

- $\quad$ Engineering International (EI)

- $\quad$ ABC Research Alert (Online)

Each journal home page provides specific information for potential authors and subscribers. Open access policy, the quick review process, rich editorial boards and quality publications have already made $A B C$ Journals unique. ABC Journals are published under the direct supervisions of renowned academicians of the world.

Collaboration in Conference: $\mathrm{ABC}$ considers high-quality conference papers for publication. Please contact us for detailed information.

Collaboration in Publishing: If you like to start writing a book, propose a new journal or advertise in $A B C$ journals, please feel free to contact us. 